\title{
DINAMIKA PLURALISME PENGGOLONGAN PENDUDUK DALAM CAPAIAN KEADILAN MENGENAI SURAT KETERANGAN WARIS
}

\author{
Putu Angga Pratama Sukma, Fakultas Hukum Universitas Mahasaraswati, \\ Email: anggasukma@unmas.ac.id
}

doi: https://doi.org/10.24843/KS.2020.v08.i09.p05

\begin{abstract}
Abstrak
Tujuan penelitian ini mengenai capaian keadilan terhadap pluralisme penggolongan penduduk, dan bentuk keadilan dalam surat keterangan waris terhadap pluralisme penggolongan penduduk. Saat ini bangsa Indonesia sangat terstigma dengan adanya penggolongan kependudukan yang tentunya tidak mencerminkan keadilan dan dapat memecah belah persatuan dan perpecahan ini tentunya mengakar dari adanya inkonsistensi norma yang bertentangan dengan keadilan sosial. Penelitian hukum ini tergolong jenis penelitian hukum normatif karena terfokus pada peraturan yang tertulis terkait dengan konflik norma antara UU Kewarganegaraan dengan Permen Agraria Tentang Pendaftaran Tanah serta kekosongan norma mengenai kewenangan pejabat dalam pembuatan atau pengesahan atau penguatan surat keterangan waris. Permen Agraria Tentang Pendaftaran Tanah tentunya harus dikesampingkan berdasarkan asas lex superior derogate legi inferiori, serta kedudukan camat tidak sah dalam penguatan surat keterangan waris. Untuk meluruskan dan menegakan aturan surat keterangan waris diperlukan dua upaya yang tujuannya berdasarkan landasan yuridis sosiologis filosofis dalam mewujudkan kepastian hukum nilai keadilan sosial serta memberikan kemanfaatan dalam pembuktian yang sempurna.
\end{abstract}

Kata kunci: Pluralisme penggolongan penduduk; Keadilan; Surat keterangan waris.

\begin{abstract}
The purpose of this research is about the achievement of justice against pluralism of classification of Indonesian citizens, and the form of justice in a certificate of inheritance against pluralism of classification of Indonesian citizens. Currently the Indonesian nation is very stigmatized by the existence of population classifications which certainly do not reflect justice and can divide unity and divisions, of course, stem from the inconsistency of norms that are contrary to social justice. This legal research is classified as a type of normative legal research because it focuses on written regulations related to the conflict of norms between the Citizenship Law and the Agrarian Ministerial Regulation on Land Registration as well as the vacuum of norms regarding the authority of officials in making or ratifying or strengthening inheritance certificates. The Agrarian Regulation on Land Registration must of course be set aside based on the principle of lex superior derogate legi inferiori, and the position of the camat is not valid in strengthening the certificate of inheritance. To straighten and enforce the rules of the certificate of inheritance, two efforts are needed whose objectives are based on juridical sociological philosophical foundations in realizing legal certainty in the value of social justice and providing benefits in perfect proof.
\end{abstract}

Keywords: Pluralism of community classification; Justice; Information on inheritance.

\section{Pendahuluan}

\subsection{Latar belakang masalah}

Indonesia dikenal sebagai negara kesatuan yang bercorak multikultural, multi etnik, agama, ras, dan multi golongan. Perbedaan corak keanekaragaman bangsa 
menyebabkan pemerintah kolonial Belanda pada jaman penjajahan menerapkan politik hukum mengenai penggolongan penduduk. Pada jaman Belanda, dalam pasal 163 I.S (Indische Staats Regeling), penduduk Indonesia dipilah menjadi 3 golongan penduduk yaitu: ${ }^{1}$

1. Golongan Eropa, menurut pasal 163 ayat (2) I.S, yang termasuk golongan Eropa adalah :

- Warga negara Belanda,

- Kaum Eropa,

- Warga negara Jepang,

- Orang-orang yang berasal dari negara lain yang hukum kekeluargaannya sama dengan hukum keluarga Belanda, terutama azas monogami,

- Keturunan mereka yang tersebut di atas.

2. Golongan Pribumi, menurut pasal 163 ayat (3) I.S, yang termasuk golongan pribumi adalah :

- Orang Indonesia asli,

- Mereka yang semula termasuk golongan lain, lalu membaurkan dirinya kedalam orang Indonesia asli.

3. Golongan Timur Asing, menurut pasal 163 ayat (4) I.S, yang termasuk golongan Timur Asing adalah mereka yang tidak termasuk dalam golongan Eropa atau Indonesia asli yaitu :

- Golongan Timur Asing Tionghoa (Cina) dan,

- Golongan Timur Asing bukan Tionghoa.

Pasca kemerdakaan Negara Indonesia penggolongan penduduk masih tetap berlaku dimana dampak penggolongan penduduk menimbulkan polemic yang luas hingga kini terutama mengenai peralihan hak atas tanah berdasarkan warisan. Pada historical awal yang membidangi pertanahan yaitu Jawatan Pendaftaran Tanah yang berada di bawah Departemen Kehakiman. Dengan adanya Surat Keputusan Presiden Nomor 190 Tahun 1957 tanggal 12 September 1957, jawatan tersebut digeser ke dalam lingkungan Kementerian Dalam Negeri menjadi Direktorat Jenderal Agraria dibawah naungan Kementerian Dalam Negeri².

Selanjutnya terbitlah Surat Keputusan Presiden Republik Indonesia Nomor 26 Tahun 1988 dibentuk Badan Pertanahan Nasional adalah sebagai peningkatan status menjadi Badan Pertanahan Nasional (BPN) yang merupakan lembaga non-departemen yang berkedudukan di bawah dan bertanggung jawab langsung kepada Presiden atau setara dengan Kementerian dengan tugas menangani bidang pertanahan secara nasional. Pada saat sebelum tahun 1998 Camat dapat mengadakan peralihan hak serta dapat menguatkan surat keterangan ahli waris dikarenakan, Camat masih berada dalam Kementerian Dalam Negeri. Mengingat Surat Mahkamah Agung tanggal 8 Mei 1991 Nomor: MA/Kumdil/171/V/K/1991 menunjuk Surat Edaran Departemen Dalam Negeri Direktorat Jenderal Agraria tanggal 20 Desember 1969 Nomor: Dpt/12/63/12/69 tentang Surat Keterangan Warisan dan Pembuktian Kewarganegaraan, secara singkat menjelaskan bahwa tidak ada satu peraturan yang

1 Sunarjati Hartono, Dari hukum antar golongan ke hukum antar adat. Bandung: Citra Aditya Bakti, (1991), h. 57.

2 Monika Ardia Ningsi Massora dan Victoria Pasari Putri. "Kekuatan Hukum Surat Keterangan Ahli Waris bagi Golongan Bumiputera yang Dikuatkan oleh Camat." Notaire 2, no. 3 (2019), h. 389. 
berwenang untuk membuat mengenai surat-surat keterangan warisan dan tidak ada hingga kini pejabat yang mempunyai kewenangan untuk membuat surat keterangan warisan.

Seorang ahli waris tidak dapat serta merta menguasai dan melakukan balik nama terhadap harta warisan yang diberikan Pewaris. Dalam hal ini ahli waris harus melakukan perbuatan hukum terhadap harta warisan yang menjadi haknya dengan keterangan waris sebagai syarat utamanya ${ }^{3}$. Pada tahun 1997 diterbitkannya Peraturan Menteri Negara Agraria/ Kepala Badan Pertanahan Nasional Nomor 3 Tahun 1997 tentang Ketentuan Pelaksanaan Peraturan Pemerintah No. 24 Tahun 1997 tentang Pendaftaran Tanah (Permen Agraria Tentang Pendaftaran Tanah) Pasal 111 ayat (1) huruf c yang berbunyi: "Permohonan pendaftaran peralihan hak atas tanah atau Hak Milik Atas Satuan Rumah Susun diajukan oleh ahli waris atau kuasanya dengan melampirkan: Surat tanda bukti sebagai ahli waris yang dapat berupa:

1) wasiat dari pewaris, atau,

2) putusan Pengadilan, atau

3) penetapan hakim/Ketua Pengadilan, atau

4) - bagi warganegara Indonesia penduduk asli: surat keterangan ahli waris yang dibuat oleh para ahli waris dengan disaksikan oleh 2 (dua) orang saksi dan dikuatkan oleh Kepala Desa/Kelurahan dan Camat tempat tinggal pewaris pada waktu meninggal dunia;

- bagi warganegara Indonesia keturunan Tionghoa: akta keterangan hak mewaris dari Notaris,

- bagi warganegara Indonesia keturunan Timur Asing lainnya: surat keterangan waris dari Balai Harta Peninggalan".

Pada tanggal 18 Agustus 2000 Konstitusi Negara Indonesia terjadi perubahan dengan menambahkan HAM dimana dalam Pasal 28 D ayat (1) menyatakan "Setiap orang berhak atas pengakuan, jaminan, perlindungan, dan kepastian hukum yang adil serta perlakuan yang sama di hadapan hukum". Dan diterbitkannya Undang-Undang Nomor 12 Tahun 2006 Tentang Kewarganegaraan (UU Kewarganegaraan) yang pada intinya hanya membedakan penggolongan penduduk menjadi dua yaitu Warga Negara Indonesia (WNI) dan Warga Negara Asing (WNA).

Hingga saat ini bangsa Indonesia sangat terstigma dengan adanya penggolongan kependudukan yang tentunya tidak mencerminkan keadilan dan dapat memecah belah persatuan dan perpecahan ini tentunya mengakar dari adanya inkonsistensi norma. Sehingga patutlah diperlukannya suatu terobosan hukum yang lebih maju dan modern. Terobosan hukum bermuara pada konstruksi pikiran untuk pembangunan hukum yang merupakan keharusan dan kemestian untuk mengarahkan hukum pada cita-cita yang diinginkan masyarakat yang berfungsi sebagai tolok ukur yang bersifat konstruktif dan regulatif.

\subsection{Rumusan Masalah}

Berdasarkan uraian diatas, maka rumusan masalah: pertama bagaimanakah capaian keadilan terhadap pluralisme penggolongan penduduk, dan kedua bagaimanakah bentuk keadilan dalam surat keterangan waris terhadap pluralisme penggolongan penduduk.

${ }^{3}$ Sari Elsye Priyanti"Tinjauan Yuridis Penggolongan Penduduk Dalam Pembuatan Keterangan Waris." Lex Renaissance 4, no. 1 (2019): h. 227. 


\subsection{Tujuan Penelitian}

Tujuan penelitian ini adalah untuk mengetahui capaian keadilan terhadap pluralisme penggolongan penduduk, dan untuk menganalisis bentuk keadilan dalam surat keterangan waris terhadap pluralisme penggolongan penduduk.

\section{Metode Penelitian}

Penelitian hukum ini tergolong jenis penelitian hukum normatif karena terfokus pada peraturan yang tertulis terkait dengan konflik norma antara UU Kewarganegaraan dengan Permen Agraria Tentang Pendaftaran Tanah serta kekosongan norma mengenai kewenangan pejabat dalam pembuatan atau pengesahan atau penguatan surat keterangan waris (Verklaring van Erfrecht). Kekosongan ini dapat memberikan dampak yang kurang baik bahkan tidak baik dalam suatu keadilan, kepastian dan kemanfaatan hukum bagi pewaris. Penelitian ini akan menggunakan beberapa jenis pendekatan antara lain: Pendekatan Perundang-Undangan (Statute Approach) dan Pendekatan Analisis Konsep Hukum (Analitical \& Conseptual Approach) ${ }^{4}$ serta Sumber Bahan Hukum yang terfokus pada bahan hukum primer, sekunder dan tersier, kemudian dikumpulkan dengan tekhnik snow ball yang analisis dengan teknik deskriptif, teknik interpretasi (penafsiran), teknik evaluasi dan teknik argumentasi.

\section{Hasil dan Pembahasan}

Hingga saat ini ketentuan dalam pembuatan surat keterangan waris di Negara Indonesia selalu didasari pada pemilahan golongan penduduk, sebagaimana dijelaskan dalam PP Pendaftaran Tanah Pasal 42 ayat (1) juncto ketentuan Permen Agraria Tentang Pendaftaran Tanah. Tentunya pembagian golongan ini memisahkan antara warganegara Indonesia penduduk asli, warganegara Indonesia keturunan Tionghoa dan warganegara Indonesia keturunan Timur Asing. Alhasil pembagian golongan penduduk ini bertentangan dengan UU Kewarganegaraan yang hanya membagi penggolongan penduduk WNI dan WNA serta bertentangan dengan Konstitusi Pasal 28 D ayat (1) "Setiap orang berhak atas pengakuan, jaminan, perlindungan, dan kepastian hukum yang adil serta perlakuan yang sama dihadapan hukum".

\subsection{Capaian Keadilan Terhadap Pluralisme Penggolongan Penduduk}

Mengakar pada falsafah keadilan sosial dimana titik tolok yang memperjuangkan dua hal: pertama, melakukan koreksi dan perbaikan ketimpangan yang dialami kelompok lemah melalui pemberdayaan lembaga sosial, ekonomi dan politik. Kedua, regulasi harus memposisikan dirinya sebagai pedoman untuk mengembangkan kebijakan untuk mengoreksi ketidakadilan yang dialami oleh yang lemah. Asas Pancasila dalam kedudukannya sebagai cita-cita hukum bangsa Indonesia dalam kehidupan bermasyarakat, berbangsa, dan bernegara tentunya merupakan bintang penuntun yang memberikan pembinaan dan pembinaan dalam segala kegiatan, memberi substansi bagi penyelesaian hukum apapun dan secara negatif. membentuk kerangka kerja yang membatasi ruang gerak konten. Hukum dan regulasi.

4 I Made Pasek Diantha Metodologi penelitian hukum normatif dalam justifikasi teori hukum. Jakarta: Prenada Media (2016), h. 88. 
Terkait dengan isi peraturan perundang-undangan, maka ketentuan tersebut baik secara sendiri-sendiri maupun bersama-sama, baik sendiri-sendiri maupun berpasangan, merupakan asas umum hukum. Selain sebagai cita-cita hukum, Pancasila juga merupakan Standar Dasar Negara (Staatsfundamentalnorm), oleh karena itu prinsip-prinsip Pancasila secara sendiri-sendiri atau bersama-sama merupakan standar dasar atau standar tertinggi bagi pelaksanaan semua standar hukum. Tingkatan perkembangan peraturan perundang-undangan dikenal dengan istilah teori tingkat hukum (Stufentheorie) yang dikemukakan oleh Hans Kelsen. Dalam teori ini, Hans Kelsen menyatakan sebagai berikut "The unity of thesenorm is constituted by the fact that the creation of one norm-the lower one-is determined by another-the higher-the creation of which is determined by a still higher norm, and that this regressus is terminated by a highest,...." 5 artinya kesatuan norma tersebut muncul dari kenyataan bahwa pembentukan suatu norma yaitu norma yang lebih rendah ditentukan oleh norma lain yang lebih tinggi dan bahwa regressus ini (rangkaian proses pembentukan hukum) diakhiri oleh norma dasar tertinggi.

Secara teori jenjang hukum (Stufentheorie) antara Permen Agraria Tentang Pendaftaran Tanah tentunya harus dikesampingkan ketika lahirnya UU Kewarganegaraan yang pada intinya hanya membagi jenis penduduk menjadi dua yakni Warga Negara Indonesia (WNI) dan Warga Negara Asing (WNA). Berdasarkan asas lex superior derogate legi inferiori yakni suatu asas yang menyatakan bahwa hukum yang tingkatannya lebih tinggi (lex superior) akan mengesampingkan hukum yang pada tingkatan yang rendah (lex inferior).

Beranjak dari adanya banyak permasalahan dan kewengan mengenai penguatan surat keterangan waris (Verklaring van Erfrecht) kedudukan camat yang memiliki tugas dan fungsi sebagai Pegawai Negeri Sipil dimana independiensinya masih diragukan dikarenakan ketika dirinya sebagai ahli waris kemungkinan dirinya menguatkan dan membernarkan atas perbuatan mengenai surat keterangan warisan tersebut. Berdasarkan UU Pemerintahan Daerah Pasal 225 yakni "Camat sebagaimana dimaksud dalam Pasal 224 ayat (1) mempunyai tugas:

a. menyelenggaraan urusan pemerintahan umum sebagaimana dimaksud dalam Pasal 25 ayat (6);

b. mengoordinasikan kegiatan pemberdayaan masyarakat;

c. mengoordinasikan upaya penyelenggaraan ketenteraman dan ketertiban umum;

d. mengoordinasikan penerapan dan penegakan Perda dan Perkada;

e. mengoordinasikan pemeliharaan prasarana dan sarana pelayanan umum;

f. mengoordinasikan penyelenggaraan kegiatan pemerintahan yang dilakukan oleh Perangkat Daerah di Kecamatan;

g. membina dan mengawasi penyelenggaraan kegiatan Desa dan/atau kelurahan;

h. melaksanakan Urusan Pemerintahan yang menjadi kewenangan Daerah kabupaten/kota yang tidak dilaksanakan oleh unit kerja Perangkat Daerah kabupaten/kota yang ada di Kecamatan; dan

i. melaksanakan tugas lain sesuai dengan ketentuan peraturan perundangundangan".

Dalam UU Pemerintahan Daerah tidak memuat tentang wewenang camat untuk mengetahui atau bahkan memperkuat surat keterangan ahli waris yang dibuat dari

${ }^{5}$ Hans Kelsen, General Theory Of Law And State, Cambridge Massachusetts U.S.A: Harvard University Press (1945), h. 124. 
ahli waris. Apakah tindakan pejabat tata usaha negara (camat) dapat dikatakan sebagai freis ermessen sehubungan dengan fungsi pelayanan publik sebagaimana dalam UU Administrasi Pemerintahan Pasal 22 yakni:

(1) Diskresi hanya dapat dilakukan oleh Pejabat Pemerintahan yang berwenang.

(2) Setiap penggunaan Diskresi Pejabat Pemerintahan bertujuan untuk:

a. melancarkan penyelenggaraan pemerintahan;

b. mengisi kekosongan hukum;

c. memberikan kepastian hukum; dan

d. mengatasi stagnasi pemerintahan dalam keadaan tertentu guna kemanfaatan dan kepentingan umum.

Berdasarkan UU Administrasi Pemerintahan Pasal 24 yakni “Pejabat Pemerintahan yang menggunakan Diskresi harus memenuhi syarat:

a. sesuai dengan tujuan Diskresi sebagaimana dimaksud dalam Pasal 22 ayat (2);

b. tidak bertentangan dengan ketentuan peraturan perundang-undangan;

c. sesuai dengan AUPB;

d. berdasarkan alasan-alasan yang objektif;

e. tidak menimbulkan Konflik Kepentingan; dan

f. dilakukan dengan itikad baik.

Surat keterangan ahli waris (Verklaring van Erfrecht) sarat akan konflik kepentingan. Ketika seorang camat atau lurah yang berasal dari wilayah tersebut dan mendapatkan harta warisan, apabila dilihat dalam Permen Agraria Tentang Pendaftaran Tanah berarti pejabat tersebut dapat memanipulasi suatu dokumen dan tentunya patut dipertanyakan mengenai independensi jabatanya terhadap dirinya. Dan juga secara keilmuan dan pengalaman Camat lebih mengarah dalam tata pemerintahan kabupaten/kota. Secara fakta surat keterangan waris yang dikuatkan dan dibenarkan oleh Camat masih terjadinya banyak sengketa, hal tersebut dikarenakan:

1. Kemungkinan tidak masuknya ahli waris lain yang tidak diketahui oleh Kepala Desa maupun Camat;

2. Bentuk dari surat keterangan waris, pernyataan waris dan silsilah waris adalah jenis keterangan sepihak karena dibuat sendiri yang diketahui oleh Kepala Desa dan dikuatkan oleh Camat;

3. Pembagian warisan tidak akan adil apabila berlandaskan itikad tidak baik dari pengajuan ahli waris untuk mengesampingkan ahli waris lainnya;

4. Semestinya terdapat pejabat khusus yang membuat keterangan waris yang tidak dapat ditampilkan oleh siapapun yang cakap dari segi keilmuan dan kekhususan suatu pejabat atau profesi hukum;

5. Sebagian ahli waris tidak memberikan keterangan yang sebenarnya mengenai nama- nama ahli waris dan objek warisan serta kurang pemahaman mengenai pembagian suatu objek warisan.

Pada pandangan umum mengenai hukum waris adalah hukum yang mengatur tentang apa yang harus dilakukan terhadap harta benda orang yang meninggal dan apa akibatnya bagi ahli waris. Dalam hukum waris berlaku prinsip bahwa hanya hak dan kewajiban di bidang hukum harta yang dapat diwariskan. Setelah meninggal, semua hak dan kewajibannya segera dialihkan kepada ahli warisnya. Warisan pada dasarnya adalah langkah-langkah untuk mentransfer dan atau mengalihkan warisan berwujud dan tidak berwujud dari ahli waris kepada ahli warisnya.

Secara fakta banyaknya sengketa mengenai ahli waris ini dikarenakan banyak penampikan oleh ahli waris dari si pengaju ahli waris padahal ahli waris ini suatu 
peristiwa penting yang tidak dapat ditampilkan oleh siapapun dan kebenarannya mutlak. Dalam UU Administrasi Kependudukan dalam Pasal 1 angka 17 adalah Peristiwa Penting adalah kejadian yang dialami pada seseorang seperti kelahiran, kematian, lahir mati, perkawinan, perceraian, pengakuan, pengesahan dan pengangkatan anak, perubahan nama dan perubahan status kewarganegaraan. Sebagi contoh: suatu kelahiran terdapat Akta Kelahiran, suatu perkawinan terdapat Akta Kawin, dan suatu kematian terdapat Akta Kematian, bila terdapat ahli waris semestinya dan seharusnya terdapat Akta Waris. Hal yang sangat penting ini sama sekali belum diakomodir oleh peraturan perundang-undangan satu pun.

Untuk mencapai suatu keadilan terhadap pluralisme penggolongan kependudukan ini semestinya Pemerintah untuk menghapus atau merubah ketentuan yang membeda-bedakan dihadapan hukum seperti Permen Agraria Tentang Pendaftaran Tanah.

\subsection{Bentuk Keadilan Dalam Surat Keterangan Waris Terhadap Pluralisme Penggolongan Penduduk}

Ketika Aristoteles ${ }^{6}$ dalam mendefinisikan keadilan korektif dengan keadilan distributif menekankan perlunya dilakukan suatu pembedaan antara pemvonisan yang mendasarkan pada keadilan dalam sifat kasus atau yang didasarkan pada watak manusia dan pembedaan ini jangan dicampuradukkan antara hukum positif yang ditetapkan dalam undang-undang dengan hukum adat, karena suatu penilaian dapat menjadi sumber pertimbangan yang hanya mengacu pada komunitas tertentu. Sedangkan penulis dalam sistem hukum di Indonesia patut untuk didasari asas Kebhinekaan dimana ketentuan hukum adat wajib diakomodir oleh hukum positif dan dapat menjadi sumber pertimbangan dalam hukum positif. Perlu diingat kembali hukum waris di Indonesia sangat berkaitan erat dengan kontek kebiasaan atau hukum adat. Tentunya perbedaan hukum adat ini menimbulkan perbedaan entah masalah bentuk, pembagian maupun ketatanan gender dalam waris di Indonesia. Perbedaan hukum adat tentu berbeda dengan penggolongan penduduk. Satu tujuan perbedaan hukum adat hanya mengenai sistem dan cara kerja pewarisan sedangkan golongan penduduknya adalah satu yakni WNI. Implikasi penggolongan penduduk baik dalam tatanan suatu peraturan perundang-undangan berdampak pada pecahnya tatanan sistem hukum dan sudah pasti inkonstitusional.

Hukum adat sangat menentukan cara kerja hukum waris dan pewarisan di Indonesia sehingga terdapat beberapa asas untuk memberikan legitimasi atas suatu pembuktian dalam surat keterangan waris. Adapun asas-asas hukum waris tersebut adalah sebagai berikut:

1) Asas Kematian (P. 830 KUHPer)

Asas ini menyatakan pewarisan hanya berlangsung karena kematian.

2) Asas Hubungan Darah dan Hubungan Perkawinan (P. 832 dan 852 KUHPer)

Asas ini beranjak dikarenakan faktor hubungan darah dan hubungan perkawinan menentukan kedekatan seseorang dengan pewaris, dan menentukan tentang berhak atau tidaknya bagi seseorang menjadi ahli waris.

3) Asas Bilateral (P. 584 KUHPer)

Asas ini menyiratkan bahwa seseorang tidak hanya mewarisi dari garis ayah, tetapi juga mewarisi dari garis ibu, juga dari saudara kandung. Prinsip ini

${ }^{6}$ Aristoteles, Politik, Diterjemahkan: Saut Pasaribu, Yogyakarta: Narasi (2017), h. 309. 
menjamin persamaan hak dan posisi antara anak laki-laki dan perempuan. Asas Bilateral juga terdeteksi dalam KUHPer, KHI, dan Hukum Adat dengan sistem kekerabatan parental. ${ }^{7}$

4) Asas Segala Hak dan Kewajiban Pewaris Beralih Kepada Ahli Waris (P. 1100 KUHPer)

Asas ini berhubungan erat dengan hak saisine, hak saisine merupakan pedoman bagi pewaris yang telah tiada bergantung pada yang masih ahli waris yang masih hidup. Berdasarkan asas hukum ini, artinya ketika seseorang meninggal dunia maka semua hartanya, baik aset maupun kewajiban, dialihkan kepada ahli warisnya. Kemudian dengan kewajiban pembayaran yang ditanggung sendiri-sendiri akan disesuaikan dengan besarnya jumlah bagian, namun tetap tidak mengurangi hak atas seluruh harta warisan selama tidak dibagikan.

Fungsi dan tujuan surat keterangan waris adalah tiga peristiwa penting dalam kehidupan manusia yaitu kelahiran, pernikahan, dan kematian. Dari ketiga peristiwa tersebut, salah satu yang rentan terhadap masalah adalah kematian, karena tidak hanya berkaitan dengan ahli waris dan harta benda, tetapi juga dengan hubungan hukum selama hidupnya, yang menimbulkan pertanyaan tentang bagaimana keadaan dan apa konsekuensi hukumnya. Hubungan hukum tersebut tidak serta merta hilang dengan meninggalnya seseorang, karena yang umumnya mereka tinggalkan tidak hanya orang atau benda, tetapi bisa juga berupa kepentingan yang berkaitan dengan anggota masyarakat lain yang membutuhkan pemeliharaan dan penyelesaian, karena jika pemeliharaan dan penyelesaian tidak dilakukan, ketidakseimbangan dalam masyarakat itu.

Kematian seseorang terkait dengan masalah warisan yang merupakan bagian dari hukum keluarga. Hukum waris sangat erat kaitannya dengan masalah harta benda yang ditinggalkan oleh ahli waris yang telah meninggal, yang dikenal dengan istilah warisan. Dalam kehidupan bermasyarakat, warisan merupakan masalah yang sensitif dan seringkali menjadi masalah dalam keluarga. Oleh karena itu, diperlukan pengaturan yang cermat dan memenuhi unsur kepastian hukum yang merupakan bukti tertulis yang menyatakan kedudukan ahli waris orang yang telah meninggal dunia dan meninggalkan warisan (ahli waris) yang dikenal dalam bentuk akta waris. Mengenai keterangan warisan, sampai saat ini belum ada peraturan yang mengatur secara khusus tentang keterangan waris.

Berdasarkan konteks pembuktian dalam hukum perdata, bukti surat akan menjadi bukti yang penting dan yang paling utama dibandingkan dengan alat bukti yang lain ${ }^{8}$. Mengacu pada ketentuan Pasal 1866 dan Pasal 1867 KUHPer, maka pembuktian dengan tulisan dilakukan dengan tulisan baik otentik maupun dibawah tangan. Surat keterangan waris harus dikeluarkan oleh pejabat yang diberi wewenang untuk membuat surat keterangan waris. Mengingat kembali Surat Mahkamah Agung tanggal 8 Mei 1991 Nomor: MA/Kumdil/171/V/K/1991 menunjuk Surat Edaran Departemen Dalam Negeri Direktorat Jenderal Agraria tanggal 20 Desember 1969 Nomor: Dpt/12/63/12/69 tentang Surat Keterangan Warisan dan Pembuktian Kewarganegaraan, secara singkat menjelaskan bahwa tidak ada satu peraturan yang berwenang untuk membuat mengenai surat-surat keterangan warisan dan tidak ada

7 Abdul Manan, "Aneka Masalah Hukum Perdata Islam di Indonesia, Jakarta: kencana (2006)., h. 208.

8 Eddy O.S. Hiariej, Teori dan Hukum Pembuktian." Jakarta: Erlangga (2012)., h. 15. 
hingga kini pejabat yang berwenang untuk membuat surat keterangan warisan. Terdapat upaya yang seharusnya Pemerintah lakukan dalam meluruskan dan menegakkan aturan surat keterangan waris: upaya pertama adalah merubah dan merevisi Permen Agraria Tentang Pendaftaran Tanah Pasal 111 ayat (1) huruf c nomor 4 mengenai penggolongan penduduk hanya ada satu yakni warga negara Indonesia (WNI), upaya kedua adalah memberikan satu kewenangan khusus kepada pejabat untuk membuat, menganalisa dan menetapkan suatu peristiwa hukum mengenai hak kewarisan kepada ahli waris berdasarkan peraturan perundang undangan yang sudah dan masih berlaku. Pada dan muaranya adalah berdasarkan landasan yuridis adalah mengamanatkan dari sila keadilan sosial dan Konstitusi Pasal 28 D ayat (1), landasan sosiologis adalah menyangkutfakta atau kenyataan empiris mengenai kemanfaatan dankebutuhan masyarakat serta negara dalam rangka menyelesaikan permasalahan berkenaan dengan surat keterangan warisan (Verklaring van Erfrecht), dan landasan filosofis mewujudkan kepastian hukum merupakan pengejawantahan dari tujuan negara yang didasari nilai-nilai keadilan sosial bagi seluruh rakyat Indonesia. Hal tersebut diilhami dalam teori cita hukum atau rechtsidee theory yang dikemukakan oleh Gustav Radbruch, sebagai suatu konstruksi pikiran yang merupakan keharusan dan kewajiban untuk mengarahkan hukum pada cita-cita yang diinginkan masyarakat yakni kepastian, keadilan dan kemanfaatan'.

Menurut penulis terkait Surat Mahkamah Agung tanggal 8 Mei 1991 serta landasan yang penulis sampaikan diatas, maka menurut hemat penulis satu kewengan khusus kepada pejabat untuk membuat, menganalisa dan menetapkan surat keterangan warisan (Verklaring van Erfrecht) adalah Notaris dan bentuk dokumen sebagai pembuktian yang sempurna harus berbentuk akta autentik. Hal tersebut didasari dari adanya kongres UINL pada tanggal 19-20 Oktober 2016 di Paris, Perancis dengan agenda yang dihasilkan adalah The Notary A Trusted Third Party yang bertujuan memperkuat peran dan fungsi Notaris dalam menjamin keberlanjutkan perekonomian. Peran dan fungsi Notaris sebagai pihak ketiga terpercaya (trusted third parties) sebagai berikut: pertama, Notary to Government dimaknai Notaris sebagai pejabat umum dimana fungsinya memberikan pelayanan kepada masyarakat dalam membangun good governance menuju clean government; kedua Notary to Busines dapat dimaknai Notaris sebagai pejabat yang berwenang untuk membuat suatu perjanjian ataupun akta; dan ketiga Notary to Society dimaknai Notaris sebagai pejabat yang terpercaya dimana fungsinya menjamin masyarakat dalam hal memberikan konsultasi atau penyuluhan hukum dan membuat wasiat dan perjanjian pra nikah. Hal ini juga selaras dengan dengan Putusan Mahkamah Konstitusi No. 69/PUU-XIII/2015 mengenai perjanjian perkawinan dapat dibuat dan sah walaupun pasca perkwinan atau telah dilangsungkannya suatu perkawinan.

\section{Kesimpulan}

Permen Agraria Tentang Pendaftaran Tanah tentunya harus dikesampingkan ketika lahirnya UU Kewarganegaraan yang pada intinya hanya membedakan penduduk menjadi dua yaitu Warga Negara Indonesia (WNI) dan Warga Negara Asing (WNA). Berdasarkan teori jenjang hukum (Stufentheorie) dan asas lex superior derogate legi inferiori. Beranjak dari adanya banyak permasalahan dan kewengan

${ }^{9}$ Ida Bagus Wyasa Putra"Teori Hukum Dengan Orientasi Kebijakan (Policy-Oriented Theory Of Law), Pemecahan Problem Konteks Dalam Proses Legislasi Indonesia. Udayana University Press, Denpasar. (2016), h. 23. 
mengenai penguatan surat keterangan waris (Verklaring van Erfrecht) kedudukan camat yang memiliki tugas dan fungsi sebagai Pegawai Negeri Sipil dalam UU Pemerintahan tidak mempunyai tugas sehingga surat keterangan waris (Verklaring van Erfrecht) berdampak menjadi tidak sah.

Fungsi dan tujuan surat keterangan waris terdapat tiga peristiwa penting dalam kehidupan manusia, yaitu kelahiran, perkawinan dan kematian. Peristiwa kematian berkaitan dengan ahli waris dan harta benda. Untuk meluruskan dan menegakan aturan surat keterangan waris diperlukan upaya: upaya pertama adalah merubah dan merevisi Permen Agraria Tentang Pendaftaran Tanah Pasal 111 ayat (1) huruf c nomor 4 mengenai penggolongan penduduk hanya ada satu yakni warga negara Indonesia (WNI), upaya kedua adalah memberikan satu kewenangan khusus kepada pejabat untuk membuat, menganalisa dan menetapkan suatu peristiwa hukum mengenai hak kewarisan kepada ahli waris berdasarkan peraturan perundang undangan yang sudah ada. Tujuannya adalah berdasarkan landasan yuridis adalah mengamanatkan dari sila keadilan sosial dan Konstitusi Pasal 28 D ayat (1), landasan sosiologis adalah empiris mengenai kemanfaatan dan kebutuhan masyarakat serta negara dalam rangka menyelesaikan permasalahan berkenaan dengan surat keterangan warisan (Verklaring van Erfrecht), dan landasan filosofis mewujudkan kepastian hukum merupakan pengejawantahan dari tujuan negara yang didasari nilai-nilai keadilan sosial bagi seluruh rakyat Indonesia. Serta diperlukan kewengan khusus kepada pejabat untuk membuat, menganalisa dan menetapkan surat keterangan warisan (Verklaring van Erfrecht) dalam bentuk dokumen yang sah sebagai pembuktian yang sempurna dalam bentuk akta.

\section{Daftar Pustaka \\ Buku}

Aristoteles. Politik, Diterjemahkan: Saut Pasaribu, Yogyakarta: Narasi (2017)

Diantha, I. Made Pasek,. Metodologi penelitian hukum normatif dalam justifikasi teori hukum. Jakarta: Prenada Media (2016)

Hans Kelsen. General Theory Of Law And State, Cambridge Massachusetts U.S.A: Harvard University Press (1945)

Hartono, C. F. G. Dari hukum antar golongan ke hukum antar adat. Bandung: Citra Aditya Bakti, (1991)

Hiariej, Eddy OS. "Teori dan Hukum Pembuktian." Jakarta: Erlangga (2012).

Manan, Abdul. "Aneka Masalah Hukum Perdata Islam di Indonesia, Jakarta: kencana (2006).

Wyasa Putra, Ida Bagus. "Teori Hukum Dengan Orientasi Kebijakan (Policy-Oriented Theory Of Law), Pemecahan Problem Konteks Dalam Proses Legislasi Indonesia. Udayana University Press, Denpasar. (2016).

\section{Jurnal}

Massora, Monika Ardia Ningsi, and Victoria Pasari Putri. "Kekuatan Hukum Surat Keterangan Ahli Waris bagi Golongan Bumiputera yang Dikuatkan oleh Camat." Notaire 2, no. 3 (2019): 389-404.

Priyanti, Sari Elsye. "Tinjauan Yuridis Penggolongan Penduduk Dalam Pembuatan Keterangan Waris." Lex Renaissance 4, no. 1 (2019): 226-247.

\section{Peraturan Perundangan}

Undang Undang Dasar Negara Republik Indonesia Tahun 1945; 
Kitab Undang-Undang Hukum Perdata (Burgerlijk Wetboek voor Indonesie);

Undang-Undang Nomor 12 Tahun 2006 Tentang Kewarganegaraan (LN 2006-63;TLN 4613 Tanggal 1 Agustus 2006);

Undang-Undang Nomor 23 Tahun 2006 Tentang Administrasi Kependudukan (LN 2006-124;TLN 4674 Tanggal 29 Desember 2006);

Undang-Undang Republik Indonesia Nomor 23 Tahun 2014 Tentang Pemerintahan Daerah (LN 2014-244;TLN 5587 Tanggal 2 Oktober 2014)

Peraturan Menteri Negara Agraria/ Kepala Badan Pertanahan Nasional Nomor 3 Tahun 1997 tentang Ketentuan Pelaksanaan Peraturan Pemerintah No. 24 Tahun 1997 tentang Pendaftaran Tanah. 